\section{Salaryman scientist}

The term "salaryman" has a pejorative connotation. Invented in Japan, it denotes a salaried employee of a large corporation, with the connotation of "time-server" or "tergiversator". The fact is that for the last hundred years or so, many scientists receive a salary and thus would appear to be salarymen. Before then, science was essentially a leisure activity and one needed to have some other source of income to provide one's daily bread. Thales of Miletus, considered to be the very first scientist, was a merchant, the revenues from which presumably paid the bills.

In practice, however, universities (whose professors, lecturers and so forth received a salary) and colleges (whose fellows received a stipend) could not be confounded with a commercial corporation or government department because universities and colleges were essentially self-governing: the professors constituted the Senate of the University and the fellows the governing body of the College. There was, however, already a tendency to devolve many powers to a smaller subset of members of the institution, typically called "Regent House", which fulfilled the same functions as the Cabinet of the British government.

Even so, careful provision was made to decouple "performance" from salary or stipend; in particular, many English universities adopted the "model statute", which declared that "academic staff have freedom within the law to question and test received wisdom, and to put forward new ideas and controversial or unpopular opinions, without placing themselves in jeopardy of losing their jobs or privileges". Indeed, without such a guarantee, the disinterestedness and objectivity of the research and scholarship carried out within the institution would be in doubt.

In recent years, however, all this has dramatically changed. In Germany, "Leistungsorientierte Belohnung" is now the norm. It does not appear to have occurred to the administrators who devised such schemes that they thereby select those who love money rather than science. England has undergone a similar transformation and most universities today are run very much along the lines of a commercial corporation. At the same time, once fairly lavish government funding is now provided with ever increasing parsimony, and universities are obliged to generate much of their income from contract research, undertaking work commissioned by commercial corporations or government departments.

It seems obvious that, by thus turning the University into a gigantic consulting organization, conflicts of interest immediately arise, well summarized by Denman:
"Truth, as one saw it [in academic life], was outspoken and expectant of contradiction, confrontation, rebuttal, denunciation and criticism. Words were not trimmed nor ideas double-thought. Straight flung speech was never considered impolite. The professional world, on the contrary, appeared to confuse politeness with deference. The shopkeepers code, the customer is always right, was the aphorism to work by. Should the client wish to think that black is white, don't disillusion him - you might lose a fee! What the French call prévenence held precedence over a hammered-out truth" [1]. Furthermore, the matter is no longer left to individual consciences. If the university administration feels that a research contract is in jeopardy due to unpalatable results, pressure will be applied on the salaried academic staff to turn the whole truth into a half-truth or less, by removing the unpalatable aspects. Formerly this could not happen because the university was an integral whole controlled by academic bodies like Senate. Now, practically speaking, power (and control of the coffers) is vested in separate administrative bodies. The fact that these bodies are acting ultra vires according to the university constitution does not seem to pose any impediment.

In the modern era of salaried scientists, those who have perceived the dangers inherent in the arrangement and acted accordingly constitute a small minority. Sir Henry Tizard is a good example: he resigned his life fellowship at Christchurch after observing the stultifying effects of such fellowships upon his seniors. The output of those scientists who have likewise eschewed the well beaten path of a salaried post is remarkable for its creativity. One may mention A.A. Griffith, James Lovelock, Peter Mitchell, George Price, Gerd Sommerhoff and Frank Whittle as examples of scientists who mostly worked outside the conventional framework, or if they were within it, achieved their best and most enduring results by clandestine activity within that framework.

That is not to say that there are no scientists working essentially as salaried employees of an institution who have achieved great things. But, in that position, there are many temptations to stray from the path of a true scientist, which means, perhaps above all, to uphold honesty and tell the whole truth. The path of least resistance may often be to accept a travesty of the truth and continue to receive one's salary, or research grant. More and more examples are coming to light. A few years ago, Scherstén et al. wrote [2]: "Two publications by Ancel Keys had a tremendous impact on the general belief of the cholesterol hypothesis. In 1953 he reported that the dietary intake of fat was significantly correlated to the serum cholesterol level and the incidence of 
cardiovascular death in 6 countries. It appeared very convincing but the problem was that these 6 countries were selected from altogether 22 countries. There was no correlation whatsoever if all the countries were included. The study was obviously a falsification." There must be many, many such examples. And the ramifications, especially regarding anything concerning health, are immense. The majority of scientists and doctors simply uncritically accept what is "in the literature". Thus, for example, in a study of cardiovascular mortality among pilots, the authors repeatedly refer to "serum cholesterol levels", which they obviously considered to be a cardiovascular risk factor [3].

Directly or indirectly, the emoluments of many scientists nowadays depend on grants disbursed by research agencies. Ensuring the continuing flow of grant money is perhaps the greatest single motivation of "scientists" to distort the truth. Often they clothe their actions in altruistic sentiments, maintaining that they have to provide the stipends and salaries of their graduate students and postdoctoral coworkers. But this is truly a wolf in sheep's clothing, for subtly or less so, those students and coworkers will learn that "untruth pays".

Furthermore, the committees that determine the allocation of grant money will inevitably - since they represent the majority — become increasingly peopled by those of a like mentality. They will vote for what supports what has become the status quo- distortion-and their majority view will prevail [4].

The loss to humanity is immense. There are prominent examples of unnecessary or even harmful drugs being aggressively promoted by pharmaceutical companies [5], but more insidious is the gradual infiltration of falsehood into the edifice of science, such that the whole structure becomes unreliable and prone to collapse.

It would be good to think that the self-correcting nature of science remains sufficiently intact to enable such abuses to be uncovered.

\section{J.J. RAMSDEN}

\section{References}

1. D.R. Denman, A Half and Half Affair, p. 305. London: Churchill Press (1993).

2. T. Scherstén et al., The cholesterol hypothesis: Time for the obituary? Scand. Cardiovasc. J. 45 (2011) 322-323.

3. H. Zeeb et al., Cardiovascular mortality of cockpit crew in Germany: cohort study. Z. Kardiol. 92 (2003) 483-489.

4. D. Gillies, Lessons from the history and philosophy of science for research assessment systems. J. Biol. Phys. Chem. 10 (2010) 158-164.

5. F. Turone, MSD Italy is criticised for threatening legal action over prescription advice to GPs. BMJ 349 (2014) g4441. 